\title{
RELATIVE INFESTATION AND DAMAGE OF SOME PIGEONPEA CULTIVARS BY LEPIDOPTERAN POD BORERS IN UGANDA
}

\author{
G. NIGHT AND M.W. OGENGA-LATIGO \\ Department of Crop Science, \\ Makerere University, \\ P. O. Box 7062, Kampala, Uganda.
}

(Received 14 March 1993; accepted 2 December 1993)

\begin{abstract}
Infestation and damage of some pigeonpea (Cajanus cajan [L.] Millsp.) cultivars by lepidopteran pod borers were evaluated over two cropping seasons during 1991 at the Makerere University Agricultural Research Institute, Kabanyolo. Significant $(P \leq \mathbf{0 . 0 5})$ cultivar differences were recorded in borer incidence and pod damage. A pio, the local cultivar, showed the highest infestation by Helicoverpa armigera (Hubner). ICPL 87104 had the greatest infestation by Maruca testulalis (Geyer), although in the second season it was not significantly higher than the rest. Etiella zinckenella (Treitschke) occurred in very low numbers, and cultivar differences were not significant $(P>0.05)$. Indexing larval counts to number of pods per plant showed that infestation pressure by both $H$. armigera and $M$. testulalis was not as different among cultivars as larval counts suggested. Pod damage was greatest on ICPL 87 and lowest on ICPL 87104.
\end{abstract}

Key Words: Pigeonpea, pod borers, Uganda

\section{RÉSUMÉ}

L'infestation et le dégâts sui quelques cultivars de pois d'Angole (Cajanus cajan (L.) Millsp.) dus aux lepidoptères foreurs des fousses ont été évalués durant deux saisons de culture en 1991, à Kabanyolo, à I'Institut de Recherche Agricole de l'Université de Makerere. Des differences signifícatives $(P \leq 0,05)$ ont été en registrées entre les variétés quant à l'incidence des foleurs et aux dégâts sur les fousses. Lé cultivar local, A pio a enregistré la plus forte infestation due à Helicoverpa armigera (Hubner). Le cultivar ICPL 87104 a enregistré la plus forte infestations due à Maruca testulalis (Geyer) même si durant la seconde saison, elle n'etait pas significativement differente des autres. Etiella zinckenella (Treitschke) a été observée en faible nombre et la difference entre les cultivars n'est pas significative $(P>0,05)$. La relation entre le nombre de larves et le nombre de fousses par plante a dé montré pue la plession d'infestation due à $\boldsymbol{H}$. armigera et $\boldsymbol{M}$. testulalis n'est pas sussi différente entre les cultivars comme le comptage des larves le laisse ressortir. Les dégâts sur les fousses ont été plus élevés sur ICPL 87 et plus bas sur ICPL 87104.

Mots Clés: Pois d'Angole, foreurs des gousses, Ouganda 


\section{INTRODUCTION}

Pigeonpea (Cajanus cajan [L.] Millsp.) is one of the major grain legume crops of the tropics and sub-tropics (Nene and Sheila, 1990). In Uganda, it is mostly grown in the drier north, where over $80 \%$ of the crop is cultivated (Acland, 1986). The most important constraints to the production of pigeonpea are the occurrence of foliar diseases, and damage by pests (Nawale and Jadhar, 1983). In East Africa, over 50 pest species have been recorded feeding on various parts of the crop (Le Pelleg, 1959). Although pest attack begins at the vegetative stage, the complex of insects feeding on pods cause the greatest damage (Chhabra et al., 1981; Lal and Yadava, 1987). Among these are the lepidopteran pod borers, Helicoverpa armigera (Hubner) (American bollworm) (Bhosale and Nawale, 1983; Kabaria et al., 1988; Tirumala et al., 1986), Maruca testulalis (Geyer) (cowpea pod borer) (Sinha et al., 1979), Etiella zinckenella (Treitschke) (legume pod borer) (Armstrong, 1991) and Exelastis atomosa (W.) (plume moth) (Odak et al., 1976).

Of the numerous pod borer species, $H$. armigera and $M$. testulalis are probably the most important pests of the crop, although their status may vary from one region to another. In India, for instance, H. armigera was reported as causing the greatest damage in Bharuch District, Gujarat (Kabaria et al., 1988), in Andhra Pradesh (Tirumala et al., 1986) and in Maharashtra (Bhosale and Nawale, 1983), while Yadava et al. (1988) reported that in Uttar Pradesh it was second in importance after the podfly, Melanagromyza obtusa (Malloch). The cowpea pod borer has also been reported as an important pest in some regions of India, such as Bihar (Sinha et al., 1979) and Orissa (Patnaik et al., 1986), particularly on early maturing varieties (Sinha et al., 1979; Yadava et al., 1988). Another lepidopteran pod borer considered important on pigeonpea is $E$. zinckenella. In Puerto Rico, together with Heliothis virescens (Fabricius), it accounts for about 50\% loss in crop yield (Armstrong, 1991).

Although pests are known to cause substantial yield losses, most of the farmers in the main pigeonpea growing regions are subsistence producers who do not apply insecticides, mainly because of resource limitation and the low economic value of the crop (Lateef and Reed,
1981; Reed et al., 1981). Under these circumstances, the use of resistant cultivars offers one of the best options for pest management on the crop. In the present study, therefore, investigation was carried out on the relative infestation and damage of some pigeonpea cultivars by lepidopteran pod borers in Uganda.

\section{MATERIALS AND METHODS}

The study was carried out at the Makerere University Agricultural Research Institute, Kabanyolo (MUARIK), during the long (LR) and short rainy (SR) seasons of 1991. The station is located about $19 \mathrm{~km}$ north-east of Kampala, at latitude $0^{\circ} 28^{\prime} \mathrm{N}$ and longitude $32^{\circ} 37^{\prime} \mathrm{E}$. In the long rains (March-June), six short-duration cultivars, namely ICPL's 85010, 87, 87104, 151, 88001 and 87111 , and seven medium-duration cultivars, ICP's 13200, 11377, 11984, 11429, 12748 and 12075 , obtained from the International Crops Research Institute for the Semi Arid Tropics (ICRISAT) and Apio (a local check) were grown. In the following season (October-December), the cultivars ICPL 151, ICPL 88001, and ICP's 11377 , 11429 and 12748 were discarded owing to their high susceptibility to Phytophthora drechsleri and $F$ usarium udum. Data for these cultivars were therefore excluded from the analyses.

The crops were grown in randomised complete blocks, with four replications. Plots measured 2.4 $\mathrm{m}$ by $5 \mathrm{~m}$, and there were five rows per plot. Interand intra-row spacings were $60 \mathrm{~cm}$ and $30 \mathrm{~cm}$, respectively. Planting dates were March 29 and October 11 in the long and short rains, respectively. Three to five seeds were planted per hole, and the plants thinned to one seedling per hill three weeks after germination. Plots were maintained by regular hand-weeding.

Ten plants, randomly selected from the second and fourth rows of each plot were examined. Infestation by $H$. armiger $a$ and $M$. testulalis was determined by counting the number of larvae on sample plants at peak incidence, 3 and 5 weeks after anthesis for short- and medium-duration cultivars, respectively.

Incidence of the legume pod borer, $E$. zinckenella, was assessed from the sample rows mentioned above at crop maturity, as this pest attacks pigeonpea late in the season (Reed et al., 1989; Badaya et al., 1990). Each of ten plants was 
TABLE 1. Infestation (number of larvae plant ${ }^{-1}$ ) of eight (short-, SD, and medium-duration, MD) pigeonpea cultivars by lepidopteran pod borers at Kabanyolo, Uganda, 1991.

\begin{tabular}{|c|c|c|c|c|c|c|}
\hline \multirow{3}{*}{$\begin{array}{l}\text { Pod borer } \\
\text { species }\end{array}$} & \multirow{3}{*}{$\begin{array}{c}\text { Pigeonpea } \\
\text { cultivar }\end{array}$} & \multirow{3}{*}{$\begin{array}{c}\text { Maturity } \\
\text { group }\end{array}$} & \multicolumn{4}{|c|}{ Cropping season } \\
\hline & & & \multicolumn{2}{|c|}{ Long rains } & \multicolumn{2}{|c|}{ Short rains } \\
\hline & & & Actual & Indexed ${ }^{\mathrm{a}}$ & Actual & Indexed \\
\hline \multicolumn{7}{|c|}{ Hellcoverpa arm/gera } \\
\hline & ICPL 85010 & $S D$ & $0.1(0.031) d^{c}$ & $0.00 \mathrm{~b}^{\mathrm{b}}$ & $0.5(0.119) \mathrm{b}$ & $0.01 \mathrm{a}$ \\
\hline & ICPL 87 & “ & $1.6(0.374) \mathrm{cd}$ & $0.11 a b$ & $5.0(0.663) \mathrm{ab}$ & $0.08 \mathrm{a}$ \\
\hline & ICPL 87104 & $"$ & $0.4(0.138) d$ & $0.01 b$ & $0.3(0.075) b$ & $0.01 \mathrm{a}$ \\
\hline & ICPL 87111 & “ & $1.0(0.291) \mathrm{cd}$ & $0.02 b$ & $2.8(0.369) a b$ & $0.03 a$ \\
\hline & ICP 11984 & MD & $3.2(0.568) \mathrm{bc}$ & $0.05 b$ & $4.0(0.600) a b$ & $0.04 a$ \\
\hline & ICP 12075 & “ & $7.1(0.832) a b$ & $0.20 \mathrm{a}$ & $6.3(0.619) a b$ & $0.09 a$ \\
\hline & ICP 13200 & “ & $1.5(0.366) \mathrm{cd}$ & $0.03 b$ & $1.5(0.325) a b$ & $0.03 a$ \\
\hline & Apio (Local) & “ & $11.3(1.081) a$ & $0.11 \mathrm{ab}$ & $10.0(0.942) a$ & $0.09 a$ \\
\hline \multicolumn{7}{|c|}{ Maruca testulalls } \\
\hline & ICPL 85010 & $S D$ & $0.7(0.203) \mathrm{bc}$ & $0.05 b$ & $0.0(0.000) a$ & $0.00 \mathrm{a}$ \\
\hline & ICPL 87 & “ & $2.2(0.437) a b$ & $0.11 \mathrm{ab}$ & $0.5(0.119) a$ & $0.01 \mathrm{a}$ \\
\hline & ICPL 87104 & “ & $3.8(0.674) a$ & $0.13 a$ & $0.5(0.119 a b$ & $0.01 \mathrm{a}$ \\
\hline & ICPL 87111 & “ & $0.5(0.148) b c$ & $0.01 b$ & $0.3(0.075) \mathrm{a}$ & $0.00 \mathrm{a}$ \\
\hline & ICP 11984 & MD & $0.0(0.000) c$ & $0.01 b$ & $0.0(0.000) a$ & $0.00 \mathrm{a}$ \\
\hline & ICP 12075 & u & $0.4(0.142) b c$ & $0.01 b$ & $0.0(0.000) a$ & $0.00 \mathrm{a}$ \\
\hline & ICP 13200 & $"$ & $0.3(0.125) b c$ & $0.01 b$ & $0.0(0.000) a$ & $0.00 \mathrm{a}$ \\
\hline & Apio (Local) & “ & $0.8(0.195) b c$ & $0.01 b$ & $0.0(0.000) a$ & $0.00 \mathrm{a}$ \\
\hline \multicolumn{7}{|c|}{ Etlella zInckenella } \\
\hline & ICPL 85010 & SD & $0.3(0.075) a$ & $0.02 a$ & $1.0(0.226) \mathrm{a}$ & $0.02 a$ \\
\hline & ICPL 87 & $“$ & $0.3(0.075) a$ & $0.01 a$ & $0.5(0.119) a$ & $0.01 \mathrm{a}$ \\
\hline & ICPL 87104 & $"$ & $1.5(0.270) a$ & $0.04 a$ & $0.3(0.075) a$ & $0.01 \mathrm{a}$ \\
\hline & ICPL 87111 & “ & $2.8(0.489) a$ & $0.03 a$ & $0.0(0.000) \mathrm{a}$ & $0.00 \mathrm{a}$ \\
\hline & ICP 11984 & MD & $2.0(0.413) a$ & $0.03 a$ & $0.5(0.119) a$ & 0.013 \\
\hline & ICP 12075 & “ & $1.0(0.270) a$ & $0.02 a$ & $0.3(0.075) a$ & $0.00 \mathrm{a}$ \\
\hline & ICP 13200 & “ & $3.0(0.445) a$ & $0.05 a$ & $0.5(0.119) a$ & $0.01 \mathrm{a}$ \\
\hline & Apio (Local) & $"$ & $0.5(0.151) \mathrm{a}$ & $0.00 \mathrm{a}$ & $0.0(0.000) a$ & $0.00 \mathrm{a}$ \\
\hline
\end{tabular}

apod-indexed infestation calculated as the ratio of number of larvae/plant to mean number of pods/ plant.

bFor each borer species in a given column, means followed by the same letter are not significantly different at $P \leq 0.05$ (Tukey's Procedure).

cFigures in parentheses are log-transformed values (transformation done to adjust variances).

harvested separately, and all pods opened and the larvae found counted.

Data for larval counts were subjected to logarithmic transformation before analysis to adjust variances. Larval counts were also converted into indices of infestation (infestation pressure) by calculating the ratio of number of pests per plant to mean number of pods per plant. Incidence of damage was assessed as the proportion of pods with borer feeding holes
(Kabaria et al., 1988; Badaya et al., 1990). Data were subjected to Analysis of Variance (ANOVA) with the linear additive model, and means compared using Tukey's Procedure.

\section{RESULTS}

Infestation by pod borers. The bollworm, $H$. armigera, was the most abundant pod borer, followed by $M$. testulalis and E. zinckenella (Table 
1). None of the cultivars was free from attack by the American bollworm. Some cultivars, however, were not infested by Maruca and E. zinckenella, particularly during the short rains. Generally, higher numbers of $H$. armigera larvae were recorded on medium-duration than on shortduration cultivars. $M$. testulalis populations, on the other hand, were higher on SD than on MD cultivars. There were no consistent differences between $\mathrm{SD}$ and $\mathrm{MD}$ cultivars in infestation by the legume pod borer. While populations of the bollworm were slightly higher in the short rains than in the long rains, infestation by both cowpea and legume pod borers were higher in the long rains than in the short rains. The highest infestation recorded for $H$. armigera in the long rains was 11 larvae plant ${ }^{-1}$, on the local cultivar, Apio. ICP 12075 also had a high population of this pest (7.1 larvae plant ${ }^{-1}$ ) (Table 1). Another cultivar which had a high population of bollworms was ICP 11984, with 3.2 larvae plant ${ }^{-1}$. Pod-indexing of the infestation revealed that ICP 12075 had the highest infestation pressure, followed by Apio and ICPL 87.

In the short rains, the cultivar Apio again had the highest infestation, but this was not significantly higher than those of other cultivars except ICPL's 85010 and 87104 (Table 1). Apio, ICP 12075 and ICPL 87 had the highest infestation indices, but differences among cultivars were not significant.

Incidence of the cowpea pod borer, $M$. testulalis, did not follow the same pattern as for the bollworm. ICPL 87104 supported the highest number of larvae (3.8 larvae plant ${ }^{-1}$ ). ICPL 87 also had a high infestation (2.2 larvae plant ${ }^{1}$ ), and was not significantly lower than that on ICPL 87104. During this season, no $M$. testulalis larvae were found on ICP 11984. Expressed as pod index, ICPL 87104 had the highest infestation pressure, followed by ICPL 87 . The indices of these two cultivars were not significantly different (Table 1).

In the short rains, ICPL's 87 and 87104 were again the most infested cultivars, although the larval populations were not significantly higher than the rest. No Maruca pod borers were found on MD cultivars. In terms of the pod index, ICPL's 87 and 87104 were still the most heavily infested. Cultivar differences were not significant.

E. zinckenella populations on the crop were generally low, particularly during the short rains. During the long rains, cultivars with high infestations included ICP 13200 (3.0 larvae plant 1), ICPL 87111 (2.8 plant $\left.^{-1}\right)$, ICP 11984 (2.0 plant 1) and ICPL $87104\left(1.5 /\right.$ plant $\left.^{-1}\right)$. Cultivar differences were, however, not significant. Using pod-indexing altered cultivar ranking for infestation. ICPL 87111, for instance, had a higher actual infestation than ICPL 87104 , but the latter had a higher indexed infestation. The relative pigeonpea infestation by $E$. zinckenella changed in the short rains. ICPL 85010, among the least infested cultivars in the long rains, supported the highest numbers of $E$. zinckenella larvae during the short rainy season. Cultivars did not differ significantly in infestation, even after indexing.

TABLE 2. Percentage of pods with feeding holes of lepidopteran pod borers for eight pigeonpea cultivars at Kabanyolo, Uganda, 1991.

\begin{tabular}{|c|c|c|c|}
\hline \multirow[b]{2}{*}{ Cultivar } & \multirow{2}{*}{$\begin{array}{c}\text { Maturity } \\
\text { group }\end{array}$} & \multicolumn{2}{|c|}{ Cropping season } \\
\hline & & Long rains & Short rains \\
\hline ICPL 87 & SD & $35.7 \pm 6.6 \mathrm{a}^{\mathrm{a}}$ & $24.9 \pm 4.7 a$ \\
\hline ICPL 85010 & SD & $19.1 \pm 3.9 \mathrm{ab}$ & $5.8 \pm 0.7 b c$ \\
\hline ICPL 87104 & SD & $16.1 \pm 0.9 b$ & $3.3 \pm 0.3 b c$ \\
\hline ICPL 87111 & SD & $18.8 \pm 2.8 \mathrm{ab}$ & $12.6 \pm 1.8 b$ \\
\hline ICP 11984 & MD & $17.4 \pm 3.2 b$ & $4.9 \pm 1.6 b c$ \\
\hline ICP 12075 & MD & $19.3 \pm 4.0 \mathrm{ab}$ & $9.1 \pm 0.6 b c$ \\
\hline ICP 13200 & MD & $18.1 \pm 2.1 b$ & $2.0 \pm 0.6 c$ \\
\hline Apio (Local) & MD & $19.12 \pm 0.4 a b$ & $12.5 \pm 0.4 b$ \\
\hline
\end{tabular}

aFor each season, means followed by the same letter are not significantly different at $P \leq 0.05$ (Tukey's Procedure). 
Pod damage. Pod damage varied significantly among cultivars, particularly in the short rainy season, and was generally higher on short-duration than on medium-duration cultivars (Table 2). Damage levels in the short rains ranged from $2 \%$ to $24.9 \%$ of pods with feeding holes, compared to a variation of 16.1 to $35.7 \%$ in the long rains. In the first rains, ICPL 87 had the highest pod damage level (Table 2). Damage levels on the other cultivars were not significantly different.

In the second season, cultivar ICPL 87 again had the highest pod damage level, being significantly higher than those on all other cultivars. ICPL 87111 and Apio also had high proportions of eaten pods (12.6 and $12.5 \%$, respectively), which were not significantly higher than for the other cultivars except ICP 13200. All other cultivars suffered less than $10 \%$ pod damage. A particularly low level of pod damage (2\%) was recorded on ICP 13200.

\section{DISCUSSION}

On the whole, pod borer infestations were higher in the long rains than in the short rains. The more luxurient plant growth in the heavier long rains probably favoured build-up of populations of these pests. Pod damage followed a similar pattern. The high variability of pod damage among cultivars in the short rains is probably due to the low occurrence of the cowpea and legume pod borers, this implying that damage observed was mainly due to the bollworm. H. armigera was the most abundant lepidopteran pod borer. Similar results have been reported from India (Bhosale and Nawale, 1983; Tirumala et al.,1986; Kabaria et al., 1988). While in the present study Maruca was second to $H$. armigera in abundance, in Orissa (India), Maruca pod borer was more important (Patnaik et al., 1986).

Short-duration cultivars were generally more infested by Maruca pod borer than mediumduration cultivars. This is similar to earlier observations from Bihar, India (Sinha et al., 1979). Since SD and MD cultivars generally had heavier infestations (both actual and pod-indexed) by Maruca pod borer and bollworm, respectively, and yet the former maturity group suffered higher pod damage, then $M$. testulalis is probably more important than actual larval numbers suggest.
Pod damage ranged from 2.0 to $35.7 \%$. These damage levels were high compared to results obtained in Orissa, India, where various pod borers, including Maruca, American bollworm and plume moth, were reported to cause 8.2 to $15.9 \%$ pod damage (Patnaik et al., 1986). However, figures obtained in the present study were lower than those obtained in other locations. At Rahuri, India, for instance, pod damage by Helicoverpa alone varied from 9.7 to $43.1 \%$ (Bhosale and Nawale, 1983). Armstrong (1991) recorded 19 to $57 \%$ pod damage by $H$. virescens and $E$. zinckenella in Puerto Rico.

Since the pod index takes into consideration resources available to insects for shelter, feeding and oviposition, it is probably a more realistic measure, particularly in relationships of infestation and damage. The observation that high pod indices do not necessarily imply high damage levels reflects differences in cultivar susceptibility to pests.

Cultivars with high infestation pressures (ratio of number of larvae per plant to mean number of pods per plant) did not necessarily have high pod damage levels. This may be attributed to some antibiotic factors, whereby high numbers of larvae per given space fed less. Cultivar ICP 12075, for instance, had high infestation indices both in the short and long rains, but low damage levels.

Another possible explanation for poor correlation between infestation pressure and damage could be differential shedding of damaged pods. Cultivars which shed more of their damaged pods may have low percentages of damaged pods. Cultivar ICP 12075 actually had a tendency to shed large numbers of pods, which were probably damaged.

From pod damage, it is apparent that cultivar ICPL 87 had the highest susceptibility to pod borers. This observation is supported by larval counts. Differences in ranking of the cultivars for borer infestation suggest that resistance/ susceptibility factors to these pests are different. This area requires further research.

\section{RERERENCES}

Acland, J.D. 1986. East African Crops. (FAO). Longmans, London.

Armstrong, A.M. 1991. Field evaluations of 
pigeonpea genotypes for resistance against pod borers. Journal of Agriculture, University P.R. 75(1):73-79.

Badaya, A.K., Das, S.B., Thakur, S.S., Shaw and Bhalla, P.L.1990. Effects of interculture operations, fertiliser application and plant protection on the incidence of borer complex on pigeonpea. Indian Journal of Plant Protection 18:27-30.

Bhosale, D.J. and Nawale, R.N. 1983. Relative susceptibility of pigeonpea germplasm to gram pod borer. Journal Maharashtra Agriculture University 8(1):30-31.

Chhabra, K.S., Kooner, B.S. and Brar, J.S. 1981. Synthetic pyrethroids for the control of the pigeonpea pest complex. Proceedings of the International Workshop on Pigeonpeas, pp 349-354. Vol. 2. Patancheru, India, 1980.

Kabaria, B., Goyal, S.N. and Shah, A.H. 1988. Surveillance of podding stage in Bharuch District, Gujarat, India. International Pigeonpea Newsletter 8: 15-16.

Lal, S.S. and Yadava, C.P. 1987. Estimation of crop losses in pigeonpea caused by pod borer complex. FAO Plant Protection Bulletin 35(3):93-98.

Lateef, S.S. and Reed, W. 1981. Development of a methodology for open-field screening for insect pest resistance in pigeonpea. Proceeaings of the International Workshop on Pigeonpeas, pp 315-322. Vol. 1. Patancheru, India, 1980.

Le Pelley, R.H.1959. Agricultural Insects of East Africa. East Africa High Commission, Nairobi, Kenya. 307pp.

Nawale, R.N. and Jadhav, L.D. 1983. Relative susceptibility of pigeonpea to pod borer damage. Journal Maharashtra Agriculture
University 8(1):94-95.

Nene, Y.L. and Sheila, V.K. 1990. Pigeonpea: Geography and importance. In Nene, Y.L., Hall, Susan D. and Sheila, V.K.(eds), pp 114. The Pigeonpea. C.A.B. International, Wallingford, Oxon, UK.

Odak, S.C., Thakur, B.S., Singh, Laxman and Shrivastava, M.P. 1976. Status and distribution of pod infesting insect species of pigeonpea in Madhya Pradesh. JNKVV Research Journal 10(4):414-415.

Patnaik, H.P., Samalo, A.P. and Samolo, B.N. 1986. Susceptibility of some early varieties of pigeonpea to pod borers under protected conditions. Legume Research 9(1):7-10.

Reed, W., Lateef, S..S. and Sithanantham, S. 1981. Pest management in low-input pigeonpea. Proceedings of the International Workshop on Pigeonpeas, pp 99-105. Vol. 1. Patancheru, India, 1980.

Reed, W., Lateef, S..S., Sithanantham, S. and Pawar, C.S. 1989. Pigeonpea and Chickpea Insect Identification Handbook. ICRIS.AT Information Bulletin No. 26. ICRISAT, Patancheru. pp 6-81.

Sinha, M.M., Yadav, R.P. and Kumar, A. 1979. Multi-directional approach for pest management in arhar (Cajanus cajan) in Bihar. Pesticides 13(11):14-16.

Tirumala, Rao K., Venugopal, Rao and Satyanarayana, Reddy, A. 1986. Control of pod borers. Indian Farming, September, 1986. pp 29, 35.

Yadava, C.P., Lal, S.S. and Sachan, J.N. 1988. Assessment of incidence and crop loss due to pod-borers of pigeonpea (Cajanus cajan) of different maturity groups. Indian Journal of Agricultural Science 58(3):216-8. 